\title{
CT-assisted thoracic sympathicolysis for therapy of primary hyperhidrosis palmaris-retrospective analysis of the influence of the amount and position of the sympathetic agent on the therapeutic outcome and side effects
}

\section{CT-gestützte thorakale Sympathikolyse zur Therapie bei primärer Hyperhidrosis palmaris - Retrospektive Analyse des Einflusses von Menge und Lage des Sympathikolytikums auf Therapieerfolg und Nebenwirkungen}

Authors

Julian Ramin Andresen', Fabian Scheer², Erik Schlöricke ${ }^{3}$, Reimer Andresen²

Affiliations

1 Medical School, Sigmund Freud Private University, Vienna, Austria

2 Institute of Diagnostic and Interventional Radiology/ Neuroradiology, Westküstenklinikum Heide, Academic Teaching Hospital of the Universities of Kiel, Lübeck and Hamburg, Heide, Germany

3 Department of Visceral, Thoracic and Vascular Surgery, Westküstenklinikum Heide, Academic Teaching Hospital of the Universities of Kiel, Lübeck and Hamburg, Heide, Germany

Key words

CT-guided thoracic sympathicolysis, minimally invasive therapy, primary palmar hyperhidrosis, sympathicolytic agent

received 13.08 .2020

accepted 15.10.2020

published online 21.12.2020

Bibliography

Fortschr Röntgenstr 2021; 193: 574-581

DOI 10.1055/a-1299-2098

ISSN 1438-9029

(C) 2020. Thieme. All rights reserved.

Georg Thieme Verlag KG, Rüdigerstraße 14,

70469 Stuttgart, Germany

Correspondence

Julian Ramin Andresen (BScMed)

Medical School, Sigmund Freud Private University,

Freudplatz 3, 1020 Vienna, Austria

Tel.: +43/6603469352

1600556@uni.sfu.ac.at

\section{ABSTRACT}

Purpose The objective of the present study was to evaluate the benefit of a thoracic, computed tomography-guided sympathicolysis (CTSy) in patients with primary, focal hyperhidrosis of the hands. In addition, the influence of the amount and distribution of the administered sympathicolytic agent was to be assessed.

Patients and Methods Retrospectively, 78 patients [13 (16.7\%) men, mean age $31.2 \pm 9$ years and 65 (83.3\%) women, mean age $34.2 \pm 12$ years], who had been treated using CTSy, were included in the study. The indication for treatment was primary focal palmar hyperhidrosis grade II and grade III after exhaustion of all conservative treatment options and a continued high level of suffering. CTSy was performed after establishing the entry plane at the level of the intervertebral space T2 / T3 via a dorsolateral approach using a 22-G coaxial needle. On average $5(2-10) \mathrm{ml}$ of a sympathicolytic mixture (10 $\mathrm{ml}$ consisting of $8 \mathrm{ml} 96 \%$ alcohol, $1.6 \mathrm{ml} 0.5 \%$ Carbostesin and $0.4 \mathrm{ml} 0.9 \% \mathrm{NaCl}$ solution, with added amounts of contrast medium) were instilled. The volume of distribution of the sympathicolytic agent was determined in craniocaudal direction using CT images. The patients evaluated their sense of discomfort preinterventionally, 2 days postinterventionally, and 6 and 12 months after the intervention, on the basis of a Dermatology life Quality Index (DLQI) as well as the side effects that occurred.

Results The technical success rate of CTSy was $100 \%$. No major complications occurred. The interventions performed led to a significant reduction $(p<0.001)$ in the preinterventional sense of discomfort 2 days, 6 and 12 months after CTSy. As the most common side effect, compensatory sweating was reported by $16 / 78(20.5 \%)$ of the patients over the further course. In all of these patients, the volume of sympathicolytic agent administered was below $5 \mathrm{ml}$. In no case did the sympathicolytic agent extend caudally beyond the base plate of 
Th 3. No compensatory sweating of the back was observed in $5 / 78$ (6.4\%) patients; here the sympathicolytic volume was above $5 \mathrm{ml}$ and extended significantly caudally below the baseplate of T3.

Transient miosis and ptosis was found in 8/78 (10.3\%) patients. In all of these patients, the volume of sympathicolytic agent administered was above $5 \mathrm{ml}$ and it extended markedly cranially beyond the upper plate of $\mathrm{T} 2$. A mild to moderate recurrent sweating developed in 35/78 (44.9\%) patients, which was more marked if the volume of sympathicolytic administered was below $5 \mathrm{ml}$ and slightly more pronounced on the left than on the right. Given a high level of satisfaction overall, 71/78 (91.0\%) patients said that they would undergo the intervention again.

Conclusion For patients with primary, focal palmar hyperhidrosis CTSy represents a therapeutic option that offers good benefit and has few side effects. The amount and spatial distribution of the sympathicolytic agent has an influence on the therapeutic outcome and the side effects.

\section{Key Points:}

- CT-assisted thoracic sympathicolysis is a minimally invasive, low-complication therapy for treatment of severe forms of primary hyperhidrosis palmaris.

- CT-assisted thoracic sympathicolysis can usually be performed on an outpatient basis.

- The quantity and local distribution of the sympathicolytic agent has an influence on the therapeutic outcome and the side effects.

\section{Citation Format}

- Andresen J, Scheer F, Schlöricke E et al. CT-assisted thoracic sympathicolysis for therapy of primary hyperhidrosis palmaris-retrospective analysis of the influence of the amount and position of the sympathetic agent on the therapeutic outcome and side effects. Fortschr Röntgenstr 2021; 193: 574-581

\section{ZUSAMMENFASSUNG}

Ziel Gegenstand der Studie war es, den Nutzen einer thorakalen, computertomografisch gestützten Sympathikolyse (CTSy) bei Patienten mit einer primären fokalen Hyperhidrose der Hände zu evaluieren. Des Weiteren sollte der Einfluss von Menge und Verteilung des applizierten Sympathikolytikums beurteilt werden.

Patienten und Methoden Retrospektiv wurden 78 Patienten (13 (16,7\%) Männer, mittleres Alter 31,2 9 Jahre, und
65 (83,3\%) Frauen, mittleres Alter 34,2 \pm 12 Jahre), die mittels CTSy behandelt wurden, in die Studie inkludiert. Die Indikation zur Behandlung war eine primär fokale Hyperhidrosis palmaris Grad II und Grad III nach Ausschöpfen aller konservativen Behandlungsmöglichkeiten und weiterhin bestehender hoher Leidensdruck. Die CTSy erfolgte nach Festlegung der Eingangsebene in Höhe des Zwischenwirbelraums BWK 2/3 über einen dorsolateralen Zugangsweg mittels einer 22GKoaxialnadel. Es wurden durchschnittlich $5(2-10) \mathrm{ml}$ eines Sympathikolytikumgemisches $(10 \mathrm{ml}$ bestehend aus $8 \mathrm{ml}$ $96 \%$ igem Alkohol, 1,6 $\mathrm{ml}$ 0,5\%igem Carbostesin und 0,4 ml $0,9 \%$ iger $\mathrm{NaCl}$-Lösung mit KM-Beimengungen) installiert. Das Verteilungsvolumen des Sympathikolytikums wurde im postinterventionellen CT-Schnittbild in kraniokaudaler Richtung ausgemessen. Die Patienten evaluierten präinterventionell, 2 Tage postinterventionell, 6 sowie 12 Monate nach der Intervention das Beschwerdeempfinden anhand eines Dermatology Quality of Life Index (DLQI) sowie der aufgetretenen Nebenwirkungen.

Ergebnisse Die technische Erfolgsrate der CTSy lag bei 100\%. Es traten keine Major-Komplikationen auf. Die durchgeführten Interventionen führten zu einem signifikanten Rückgang $(p<0,001)$ des präinterventionellen Beschwerdeempfindens 2 Tage, 6 und 12 Monate postinterventionell nach CTSy. Als häufigste Nebenwirkung gaben 16/78 (20,5\%) Patienten im Verlauf ein kompensatorisches Schwitzen am Rücken an. Bei all diesen Patienten lag das Sympathikolytikumvolumen unter $5 \mathrm{ml}$, das Sympathikolytikum überschritt in keinem Fall die Grundplatte von BWK 3 nach kaudal. Kein kompensatorisches Schwitzen am Rücken zeigte sich bei 5/78 (6,4\%) Patienten, hier lag das Sympathikolytikumvolumen über $5 \mathrm{ml}$ und dehnte sich deutlich nach kaudal unterhalb der Grundplatte von BWK 3 aus. Eine passagere Miosis und temporäre Ptosis fand sich bei 8/78 (10,3\%) Patienten. Bei all diesen Patienten lag das Sympathikolytikumvolumen über $5 \mathrm{ml}$ und dehnte sich deutlich nach kranial oberhalb der Deckplatte von BWK 2 aus. Ein leichtes bis mäßiges Rezidivschwitzen entwickelte sich bei 35/78 (44,9\%) Patienten, deutlicher bei applizierten Volumina des Sympathikolytikums unter $5 \mathrm{ml}$ und links etwas ausgeprägter als rechts. Bei einer insgesamt hohen Zufriedenheit würden 71/78 (91,0\%) Patienten die Intervention wieder durchführen lassen. Schlussfolgerung Die CTSy stellt für Patienten mit primärer fokaler Hyperhidrosis palmaris eine nebenwirkungsarme Therapieoption mit gutem Benefit dar. Die Menge und die räumliche Verteilung des Sympathikolytikums haben einen Einfluss auf den therapeutischen Effekt und die Nebenwirkungen.

\section{Introduction}

The disease pattern of primary (idiopathic, essential) hyperhidrosis is characterized by localized sweat secretion exceeding the normal physiological level, which can lead to a considerable amount of psychological distress [1]. Excess sweating is the most common symptom of primary hyperhidrosis (95\%), with in- creased sympathetic tone being the cause, leading to increased innervation of eccrine sweat glands. Secondary hyperhidrosis, which is comparatively rare ( $5 \%$ ), is caused by disorders of the endocrine, neurological and cardiovascular systems. Since the disease is found in infectious, systemic, and malignant diseases, as well as obesity and as side effects of various drugs, it must be clarified by differential diagnosis [2-4]. Worldwide, the prevalence of 
primary hyperhidrosis varies from $0.6 \%$ to $16.3 \%$ [5], with up to $1 \%$ in Israel [6], $2.8 \%$ in the US as a whole [7], 1-2\% in Europe [8] and up to $14.7 \%$ in Brazil [9], although reliable data are not yet available due to varying surveys. Another possible source of discrepancy is the divergent approach to the disease in different countries [10]. Although both sexes are equally affected, more women undergo medical treatment, which could be due to a significantly higher level of distress among female patients [11]. There is a familial disposition in $30-50 \%$ of patients but the mode of inheritance is not yet uniformly clarified [12]. In patients with a severe form of hyperhidrosis there is evidence of autosomal dominant inheritance with incomplete penetrance [12].

Primary focal hyperhidrosis can affect the palms of the hands (palmar hyperhidrosis), the soles of the feet (plantar hyperhidrosis), the armpits (axillary hyperhidrosis) and the face (facial hyperhidrosis); combined manifestations are most common. The palmar form usually begins in the 2nd to 3 rd decade of life; Estevan et al. [5] found a mean age of 22 (16-29) years in 615 patients. The therapy of mild to moderate hyperhidrosis is primarily conservative, whereby topical treatment with antiperspirants, tap water iontophoresis, systemic administration of anticholinergics and psychotherapy (biofeedback) are possible [1, 13]. Local botulinum toxin injections [14] and the excision of the thoracic border strand by video-thoracoscopic sympathectomy $[6,15,16]$, CTSy $[8,17$, 18] or CT-guided radiofrequency neurolysis [19] are available for a severe form of palmar hyperhidrosis. Prior to any therapy as well as follow-up, it is essential to objectively assess the severity and subjective impairment ( $>$ Table 1) [20]; reliable tools and questionnaires are available for this purpose [20, 21, 23].

The objective this study was to evaluate the benefit of thoracic computed tomography-guided sympathicolysis (CTSy) in patients with severe primary, focal hyperhidrosis of the hands as well as assess the influence of quantity and distribution of the applied sympathicolytic agent on therapy success in addition to side effects.

\section{Patients and Methods}

Retrospectively, the study included 78 patients [13 (16.7\%) men, mean age $31.2 \pm 9$ years and 65 (83.3\%) women, mean age $34.2 \pm$ 12 years], who had been treated using CTSy. The treatment period extended from 2017 to 2019, with all patients having had the intervention at least 12 months prior to the time of data collection.

The indication for treatment was primary focal palmar hyperhidrosis grade II and grade III after exhaustion of all conservative treatment options and a continued high level of suffering ( $\triangleright$ Table 1 ) [20].

Possible disturbance of the blood coagulation function or contrast agent intolerance was clarified and ruled out in advance. The intervention was explained a few days in advance of the procedure.

For the intervention, patients were positioned in prone position in CT (GE Revolution EVO/64-line CT, Wauwatosa, WI, USA). A craniocaudal spiral of the thoracic spine region from T1 to T4 was then performed using a low-dose technique. Sedation with $2 \mathrm{mg}$ midazolam was performed as needed. After determining
- Table 1 Severity classification of palmar hyperhidrosis, modified according the the $\mathrm{S} 1$ guideline: Definition and therapy of primary hyperhidrosis [20] and comparison with subjective perception.

\begin{tabular}{|l|l|l|}
\hline severity & symptoms & $\begin{array}{l}\text { subjective } \\
\text { perception }\end{array}$ \\
\hline $\begin{array}{l}\text { grade I: light } \\
\text { hyperhidrosis }\end{array}$ & $\begin{array}{l}\text { significantly increased } \\
\text { skin moistness }\end{array}$ & $\begin{array}{l}\text { no impairment to } \\
\text { discrete distress in } \\
\text { daily life }\end{array}$ \\
\hline $\begin{array}{l}\text { grade II: moderately } \\
\text { heavy hyperhidrosis }\end{array}$ & $\begin{array}{l}\text { formation of drops of } \\
\text { sweat }\end{array}$ & $\begin{array}{l}\text { moderate to signifi- } \\
\text { cant distress in daily } \\
\text { life }\end{array}$ \\
\hline grade III: heavy & $\begin{array}{l}\text { dripping beads of } \\
\text { sweat, perspiration } \\
\text { also on the back of } \\
\text { the hands and fingers }\end{array}$ & $\begin{array}{l}\text { severe impairment in } \\
\text { everyday life (with } \\
\text { negative influence on } \\
\text { job and social }\end{array}$ \\
\hline & & \begin{tabular}{l} 
contacts) \\
\hline
\end{tabular} \\
\hline
\end{tabular}

the access level in the axial CT cross-section, skin disinfection and local anesthesia, a dorsolateral access was made at the level of the intervertebral space of T2/3. A 22-G $10 \mathrm{~cm}$ coaxial needle (Chiba Biopsy Needle, COOK Medical, Bloomington, USA) was then successively advanced to the ventral third of the lateral vertebral body boundary, with the tip of the needle lying between the parietal pleura, the cortex of the vertebral body and dorsally to the trachea and esophagus ( $\triangleright$ Fig. 1a). On average $5(2-10) \mathrm{ml}$ of a sympathicolytic composite $(10 \mathrm{ml}$ consisting of $8 \mathrm{ml} 96 \%$ alcohol, $1.6 \mathrm{ml} 0.5 \%$ Carbostesin and $0.4 \mathrm{ml} 0.9 \% \mathrm{NaCl}$ solution, with added amounts of contrast medium) were injected. During the intervention, the immediate effect of sympathicolysis was documented by measuring the temperature of the back of the hand of the corresponding extremity with an infrared thermometer (BRAUN ThermoScan, Kronberg/Taunus, Germany).

After completing the final spiral with coronary and sagittal reformation as well as $3 \mathrm{D}$ reconstruction ( $\vee$ Fig. $\mathbf{1 b}$ ), the distribution of the sympathicolytic mixture was measured in the craniocaudal direction ( $>$ Fig. 2 a, b).

In order to be able to react adequately to a possible complication or an unwanted spread of the sympathicolytic agent, a single, bilateral approach was never used. The intervention on the second side took place at intervals of 1-4 weeks, with all patients receiving care on both sides. In 74 of 78 (94.9\%) patients the sympathicolysis was performed on an outpatient basis, in 4 of $78(5.1 \%)$ patients as an inpatient. When the sympathicolytic agent was properly spreading after the intervention, the patients were positioned on their backs in bed with a slightly elevated upper body. In the event of undesired distribution of the drug mixture, the patient was repositioned to minimize side effects. After two hours of post-interventional monitoring, the outpatients could be discharged, the inpatients the following day.

Based on the Dermatology life Quality Index (DLQI) [21], the patients evaluated their sense of discomfort prior to the intervention, then 2 days postinterventionally, and 6 and 12 months subsequently. This took place during a previously determined outpa- 


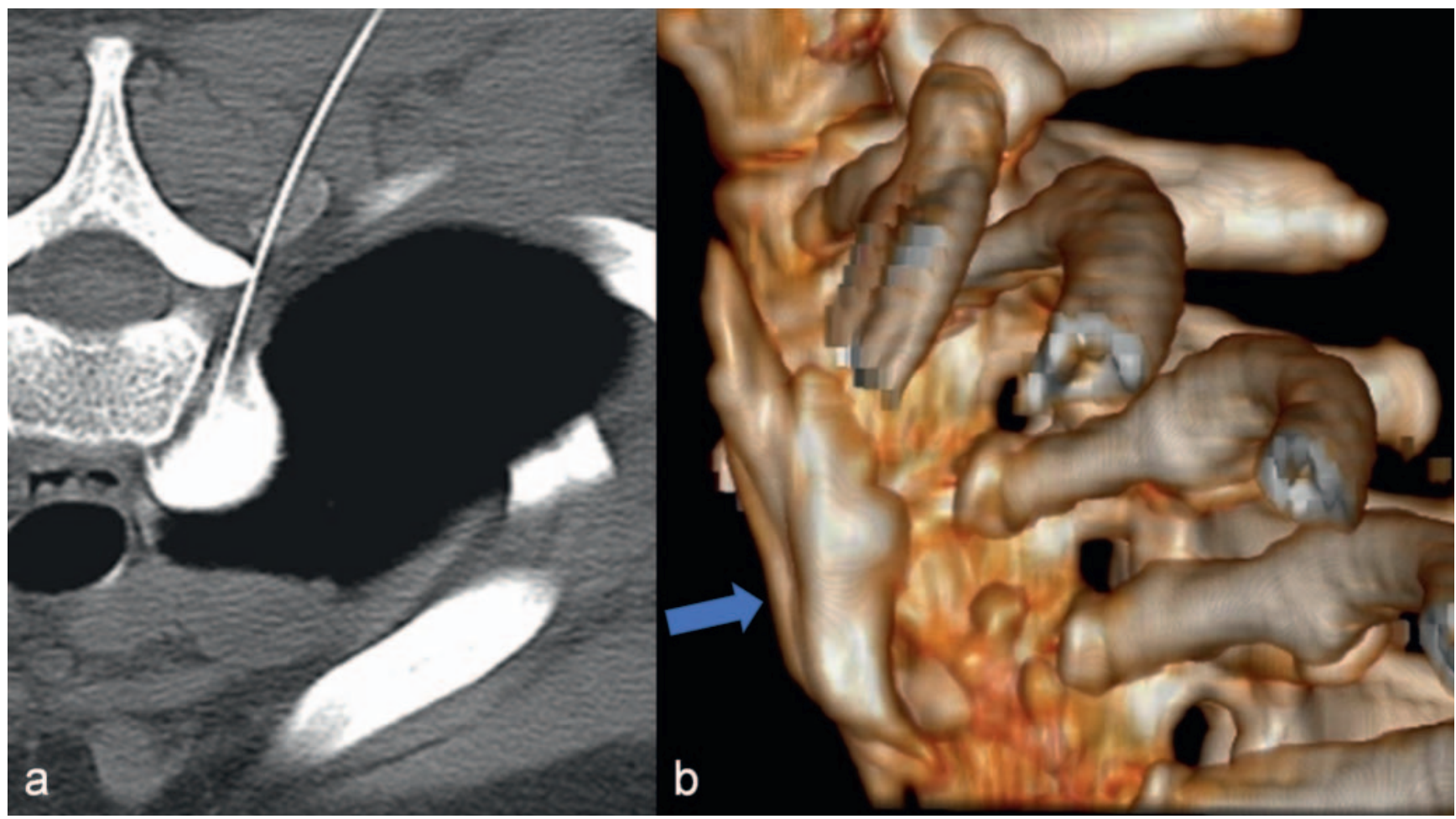

- Fig. 1 a Distribution of the $5 \mathrm{ml}$ drug mixture paravertebrally on the left at the level of the pedical of the vertebral arch T3 in the axial CT crosssectional image, $\mathbf{b}$ The $3 \mathrm{D}$ reconstruction shows the extent of the sympathicolytic agent in the cranial direction with branching up to the top plate of $\mathrm{T} 1$ and in the caudal direction with branching to the baseplate of $\mathrm{T} 3$.

tient appointment at the clinic. The assessment could achieve overall values between 0 and 30 points, where $A: 0-1=$ no impact; B: 2-5 = limited impact; C: 6-10=moderate impact; D: 1120 = very great impact; and E: $21-30=$ extremely great impact on the patient's quality of life. To determine side effects, miosis, ptosis, dyspnea, neuralgia, paresthesia, gustatory and compensatory sweating as well as recurrent sweating were investigated and surveyed. Complications were recorded according to the CIRSE classification [22]. Finally, the patients were asked about their satisfaction and willingness to have the therapy performed again.

Statistical analysis was performed using Prism 5 software (GraphPad). The Wilcoxon rank sum test for paired samples was used as a statistical test procedure to check the differences in DLQI values over time. Statistical significance was indicated as ${ }^{*} \mathrm{p}<0.05,{ }^{* *} \mathrm{p}<0.005$ and ${ }^{* * *} \mathrm{p}<0.0005$.

\section{Results}

The technical success rate of CTSy was $100 \%$. During the intervention all patients developed a significant temperature increase of $1-3{ }^{\circ} \mathrm{C}(\mathrm{p}<0.005)$ on the back of the hand on the treated side. The interventions performed led to a significant reduction $(p<0.001)$ in the preinterventional experience of discomfort 2 days, 6 and 12 months after CTSy. The effect decreased over the course of 6 and 12 months, but without reaching the level of the pre-interventional experience of symptoms ( $>$ Fig. 3, 4).

There were no major complications such as pneumothorax, hemorrhage or infection. There were no complications or side effects requiring additional or further therapy according to the CIRSE classification.

The most common side effect over time, compensatory sweating in the trunk area, was reported by $16 / 78$ (20.5\%) of the patients; this started on average 5 weeks after intervention and decreased significantly after 6-12 months. In all of these patients, the volume of sympathicolytic agent administered was below $5 \mathrm{ml}$, and in no case did it extend caudally beyond the baseplate of T3.

Transient miosis and/or temporary ptosis was found in 8/78 (10.3\%) patients, and none developed full Horner syndrome. Within one week the symptoms diminished completely. In all of these patients, the volume of sympathicolytic agent administered was above $5 \mathrm{ml}$ and it extended markedly cranially beyond the end plate of $\mathrm{T} 2$.

Mild to moderate recurrent sweating with renewed minor effects developed in 35/78 (44.9\%) patients, which was more marked if the volume of sympathicolytic administered was below $5 \mathrm{ml}$ and slightly more pronounced on the left side than on the right ( $\triangleright$ Table 2 ).

A sustained positive effect was demonstrated over a period of 12 months. Given a high level of satisfaction overall, 71/78 $(91.0 \%)$ patients said that they would undergo the intervention again. 


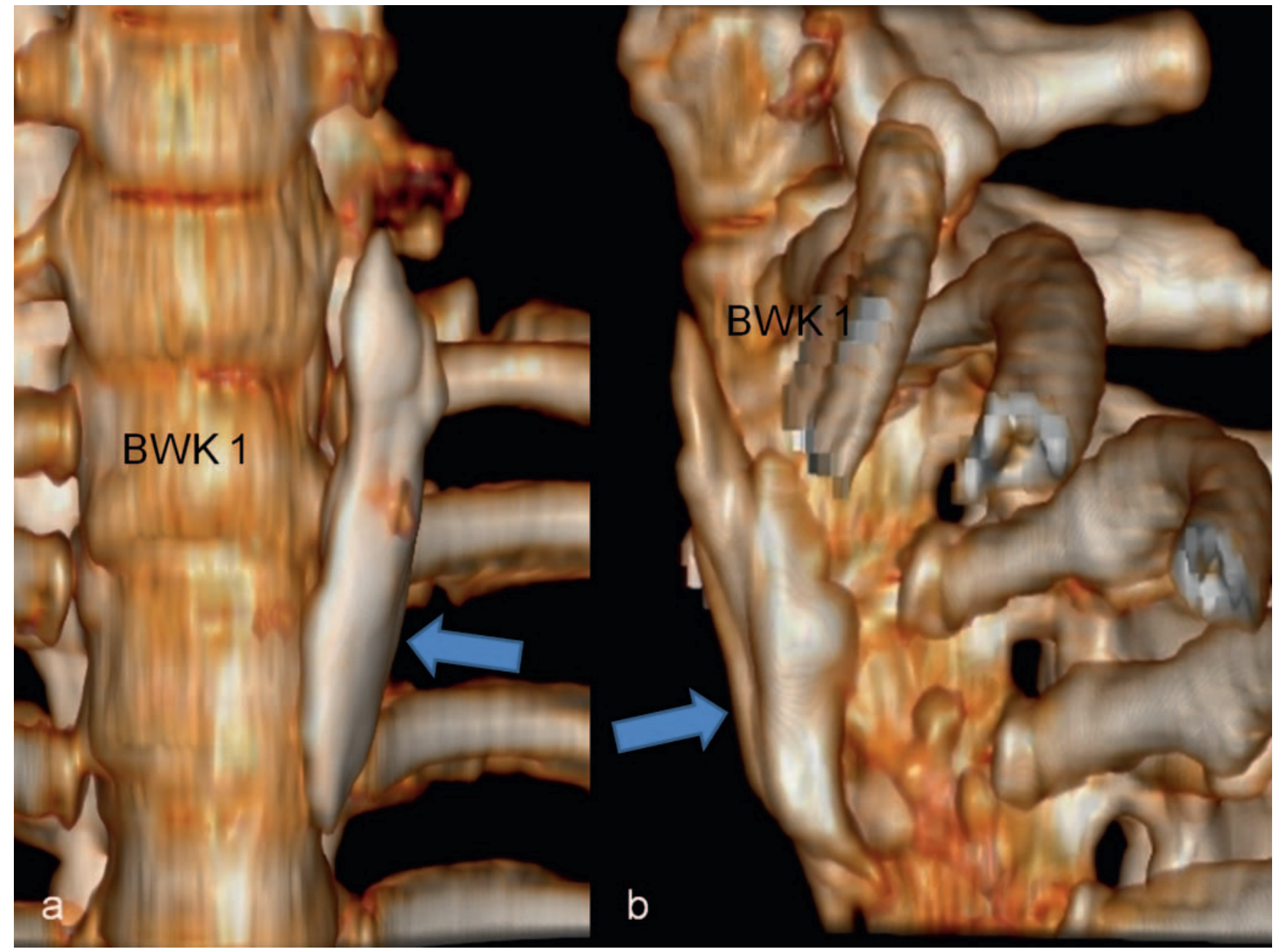

- Fig. 2 In the $3 \mathrm{D}$ reconstruction of the paravertebral sympathicolytic agent with an extension cranially up to the upper third of $\mathrm{C} 7$ and caudally up to the top plate of $\mathrm{T} 3 \mathbf{a}$ as well as cranially up to the upper third of $\mathrm{T} 1$ and caudally up to top plate $\mathrm{T} 4 \mathbf{b}$.

\section{Discussion}

After all conservative measures have been exhausted, CTSy of the thoracic sympathetic trunk is considered a possible adjuvant therapy option for severe, therapy-resistant primary palmar hyperhidrosis [20]. Using CT-guided insertion it is possible to reproducibly and exactly apply a neurolytic agent to the thoracic sympathetic trunk. In the case of palmar hyperhidrosis, the inserted needle tip should be located paravertebrally on the ventrolateral third of the vertebral body at the level of T2 / T3 [18, 24], in the case of additional axillary hyperhidrosis, the needle tip should be inserted a little further caudally at the T3 level [24]. Phenol [17, 25] or alcohol [18, 24] are used as sympathicolytic agents. However, due to the lower phenol concentration ratios, large volume injections are required for effective sympathicolysis [25], so that nowadays high-percentage alcohol injections are favored $[18,24]$ to achieve a more precise distribution at the sympathetic nerve system with smaller volumes. As a rule, between 2-6 $\mathrm{ml}$ of alcoholic sympathicolytic solution are applied [18, 24], whereby $2 \mathrm{ml}$ already show good effects in terms of sweat reduction [24]. A measurable local temperature increase, which developed in all our patients, served as an objective sign of successful sympathicolysis. With an amount of the sympathicolytic $>5 \mathrm{ml}$ and a distribution in the cranial direction above the basal plate of $\mathrm{T} 1,10.3 \%$ of the patients developed temporary miosis and ptosis; the possible cause is accidental irritation through edema or direct damage to the caudal portions of the cervicothoracic ganglion [26]. Elevating the upper body immediately after the intervention prevents the sympathicolytic agent from spreading cranially and minimizes irritation of the cervicothoracic ganglion [18].

Compensatory sweating is found in our patients to varying degrees with an overall incidence of $20.5 \%$, compared with Brock et al. [24] $16 \%$ and Scheer et al. [18] 38.9\%.

The most common compensatory sweating at $20.5 \%$ is found with an amount of the sympathicolytic $<5 \mathrm{ml}$ and expansion not further caudally than the baseplate of T3. In contrast, there is a frequency of $0 \%$ if the sympathicolytic is $>5 \mathrm{ml}$ and extends caudally to the baseplate of T4. This is also found analogously to thoracoscopic sympathectomy; treatment at the level of T2 leads to a higher rate of compensatory sweating than a treatment of T3 [27]. In order to minimize compensatory sweating and taking these findings into account, in the future, the sympathicolytic 


\section{0}

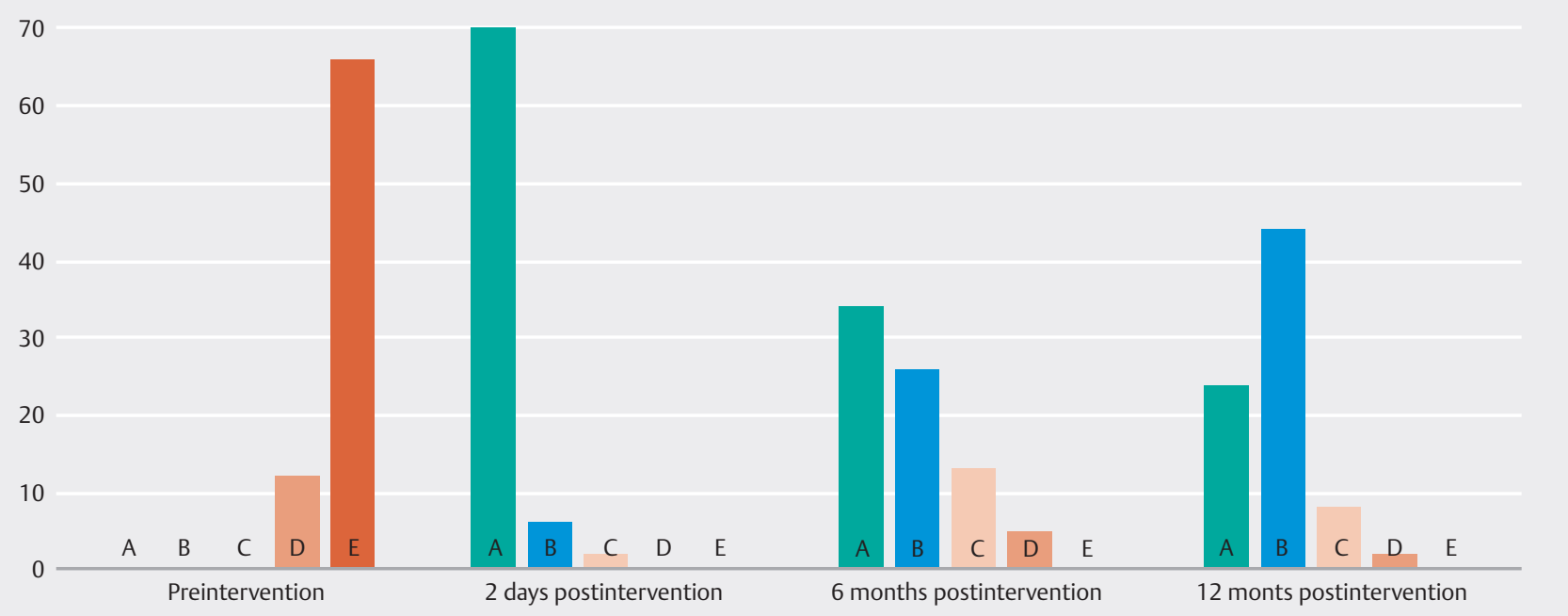

- Fig. 3 Development of hyperhidrosis, based on symptom perception according to the DLQI: (A corresponds to $0-1$ score points = no impact, B corresponds to $2-5$ score points $=$ minor impact, $C$ corresponds to $6-10$ score points $=$ moderate impact, $D$ corresponds to $11-20$ score points = very great impact and $\mathrm{E}$ corresponds to $21-30$ score points = extremely great impact on quality of life). From the pre-interventional to postinterventional 2nd day, there is a shift in degrees of severity to the left, which is an expression of a significantly improved quality of life. Slight deterioration develops over time, but remains better than the preinterventional impairment even after 12 months post-intervention.

- Table 2 Spectrum of side effects indication of the relative frequencies as a function of the amount and distribution of the sympathicolytic agent.

\begin{tabular}{|l|l|l|l|}
\hline $\begin{array}{l}\text { quantity of } \\
\text { sympathicolytic agent }\end{array}$ & $\begin{array}{l}\text { distribution of } \\
\text { sympathicolytic agent }\end{array}$ & $\begin{array}{l}\text { relative frequency and } \\
\text { significance of side effects [\%] }\end{array}$ \\
\hline$>5$ & to above baseplate of T1 & transient miosis, temporary ptosis & $10,3(p<0.05)$ \\
\hline$>5$ & from T1-T3 & dyspnea & 0 \\
\hline$>5$ & to baseplate of T4 & compensatory sweating & 0 \\
\hline$<5$ & maximal to baseplate of T3 & compensatory sweating & $20.5,(p<0.05)$ \\
\hline$<5$ & T2-T3 & recurrent sweating & $44.9,(p<0.001) ;$ and left $>$ right \\
& & & $(p<0.05)$ \\
\hline
\end{tabular}

agent should be applied caudally in an amount of a $5 \mathrm{ml}$, not at the level of T2 / T3 but rather half a vertebral body height further in the caudal direction. This also reduces the proportion of the sympathicolytic that rises cranially, which can reduce the probability of irritation of the cervicothoracic ganglion.

In the course of 12 months, the majority of cases show a decrease of the sympathicolytic effect with a relative frequency of recurrent sweating of $44.9 \%$, but in no case does the DLQI level decline to the initial level after previous improvement. Despite the loss of the effect, none of our patients decided to repeat sympathicolysis, they were sufficiently satisfied with the result achieved and did not need re-intervention for optimal enjoyment of their quality of life. The recurrence of sweating was found to be conspicuously frequent with the applied amounts of sympathicolytic $<5 \mathrm{ml}$ and a distribution between $\mathrm{T} 2$ and $\mathrm{T} 3$, and more pronounced on the left hand than on the right. The cause of the recurrent sweating, especially with lower amounts of sympathicolytic agents, appears to be a possible regeneration of the nerves [18]. In addition, nerve short-circuits with variable proportions between the 1 st to 4 th intercostal nerves, which bridge the $2^{\text {nd }}$ and $3^{\text {rd }}$ sympathetic ganglion up to the brachial plexus, are of great importance [28]. These nerve tracts can contribute to recurrent sweating since they are usually only peripherally contacted or not at all by the sympathicolytic agent or a sympathectomy due to a mean distance $>7 \mathrm{~mm}$ from the thoracic sympathetic trunk [18, 29]. A possible explanation for a more pronounced recurrent sweating for our patients on the left side may be a stronger and more frequent expression of the nerve of Kuntz [30] as a variable neural connection between the $1^{\text {st }}$ and $2^{\text {nd }}$ ventral ramus of spinal nerves 1 and 2 proximal to the exit of the brachial plexus on the left side [31]. After CTSy, recurrent sweating is somewhat more frequent and more pronounced than after a video-thoracoscopic 
30

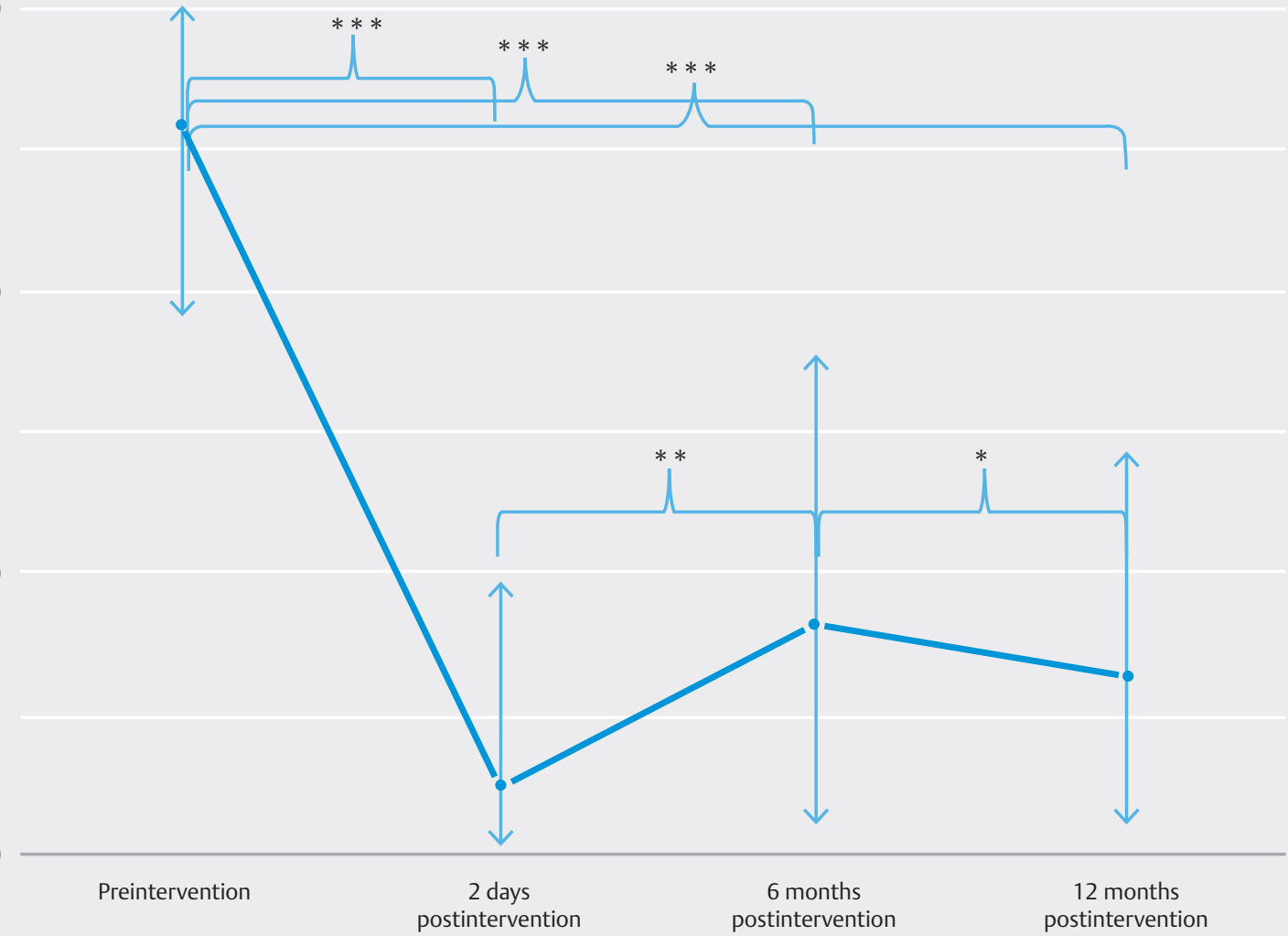

- Fig.4 Development over time of mean DLQI after thoracic sympathicolysis. There is a significant improvement in the quality of life over the entire observed period $\left({ }^{*} \mathrm{p}<0.05 ;{ }^{* *} \mathrm{p}<0.005 ;{ }^{* * *} \mathrm{p}<0.0005\right)$. Moderate deterioration in the DLQI values develop after 6 months, mainly due to compensatory sweating on the trunk. After 12 months there is a slight improvement in DLQI values; this is due to a decrease in compensatory sweating on the trunk of the body. Now the recurrent sweating on the hands with a moderate impairment is apparent, but it is clearly and significantly less than before treatment.

sympathectomy (VATS) [32]. On the other hand, there are greater major complications, such as pneumothorax and pain after thoracotomy using VATS [32]. For patients with severe palmar hyperhidrosis, both procedures represented a minimally invasive treatment option with good, lasting and largely equivalent benefit $[18,32,33]$. Another significant advantage of CTSy compared to VATS, however, is that it can be performed on an outpatient basis while avoiding general anesthesia and bed confinement, can be repeated as required and is therefore the preferred method.

\section{Conclusions}

For patients with primary, focal palmar hyperhidrosis, after conservative measures have been exhausted, CTSy represents a therapeutic option offering good benefit with few side effects. The amount and spatial distribution of the sympathicolytic agent has a significant influence on the therapeutic outcome and side effects.

\section{Conflict of Interest}

The authors declare that they have no conflict of interest.

\section{References}

[1] Hornberger J, Grimes K, Naumann M et al. Recognition, diagnosis and treatment of primary focal hyperhidrosis. J Am Acad Dermatol 2004; 51 : 274-286

[2] Walling HW. Clinical differentiation of primary from secondary hyperhidrosis. J Am Acad Dermatol 2011; 64: 690-695

[3] Wolosker N, Krutman M, Kauffman P et al. Effectiveness of oxybutynin for treatment of hyperhidrosis in overweight and obese patients. Rev Assoc Med Bras (1992) 2013; 59: 143-147

[4] Nawrocki S, Cha J. The etiology, diagnosis, and management of hyperhidrosis: A comprehensive review: Etiology and clinical work-up. J Am Acad Dermatol 2019; 81: 657-666

[5] Estevan FA, Wolosker MB, Wolosker $\mathrm{N}$ et al. Epidemiologic analysis of revalence of the hyperhidrosis. An Bras Dermatol 2017; 92: 630-634

[6] Hashmonai M, Assalia A, Kopelman D. Thoracoscopic sympathectomy for palmar hyperhidrosis. Surg Endosc 2001; 45: 435-441

[7] Strutton DR, Kowalski JW, Glaser DA et al. US prevalence of hyperhidrosis and impact on individuals with axillary hyperhidrosis: results from a national survey. J Am Acad Dermatol 2004; 51: 241-248

[8] Lucas A, Rolland $\mathrm{Y}$, Journeaux $\mathrm{N}$ et al. Computed tomography guided thoracic sympathicolysis for palmar hyperhidrosis. J Cardiovasc Surg 1998; 39: 387-389 
[9] Lima SO, Aragão JF, Machado Neto J et al. Research of primary hyperhidrosis in students of medicine of the State of Sergipe, Brazil. An Bras Dermatol 2015; 90: 661-665

[10] Adar R. Surgical treatment of palmar hyperhidrosis before thoracoscopy: experience with 475 patients. Eur J Sur 1994; 572: 9-11

[11] Tabet JC, Bay JW, Magdinec M. Essential hyperhidrosis. Current therapy. Cleveland Clin Q 1986; 53: 83-88

[12] Kaufmann H, Saadia D, Polin C et al. Primary hyperhidrosis: Evidence for autosomal dominant inheritance. Clin Auton Res 2003; 13: 96-98

[13] Connolly M, De Berker D. Management of primary hyperhidrosis - a summary of the different treatment modalities. Am J of Clin Dermatol 2003; 4: 681-697

[14] Krogstad AL, Skymne BS, Goran-Pegenius BS et al. Evaluation of objective methods to diagnose palmar hyperhidrosis and monitor effects of botulinum toxin treatment. Clin Neurophysiol 2004; 115: 1909-1916

[15] Little AG. Video-assisted thoracic surgery sympathectomy for hyperhidrosis. Arch Surg 2004; 139: 586-589

[16] Milanez de Campos JR, Kauffman P, Gomes O Jr et al. Video-assisted thoracic sympathectomy for hyperhidrosis. Thorac Surg Clin 2016; 26 : 347-358

[17] Adler OB, Engel A, Rosenberger A et al. Palmar Hyperhidrosis: CT guided chemical percutaneous thoracic symathectomy. Fortschr Röntgenstr 1990; 153: 400-403

[18] Scheer F, Wins A, Kamusella P et al. [Clinical importance of CT-assisted sympathicolysis in primary, focal plantar and palmar hyperhidrosis]. Fortschr Röntgenstr 2012; 184: 624-628

[19] García-Barquín P, Aquerreta Beola JD, Bondía Gracía JM et al. Percutaneous CT-guided sympathicolysis with radiofrequency for the treatment of palmar hyperhidrosis. J Vasc Interv Radiol 2017; 28: 877-885

[20] Rzany B, Bechara FG, Feise $K$ et al. Update of the S1 guidelines on the definition and treatment of primary hyperhidrosis. JDDG 2018; 16: 945952

[21] Finlay AY, Khan GK. Dermatology Life Quality Index (DLQI) - a simple practical measure for routine clinical use. Clin Exp Dermatol 1994; 19: 210-216

[22] Filippiadis DK, Binkert C, Pellerin O et al. Cirse Quality Assurance Document and Standards for Classification of Complications: The Cirse Classification System. Cardiovasc Intervent Radiol 2017; 40: 1141-1146
[23] Solish N, Bertucci V, Dansereau A et al. A comprehensive approach to the recognition, diagnosis, and severity-based treatment of focal hyperhidrosis: recommendations of the Canadian Hyperhidrosis Advisory Committee. Dermatol Surg 2007; 33: 908-923

[24] Brock M, Frangakis C, Georgiades CS. CT-guided, percutaneous ethanol sympatholysis for primary hyperhidrosis. Cardiovasc Intervent Radiol 2018; 41: 477-482

[25] Dreyfus A, Fondras JC, Loubrieu G et al. [Thoracic sympathectomy by phenol injection under $\mathrm{x}$-ray computed tomography. Two initial results]. Agressologie 1990; 31: 210-211

[26] Noppen M, Herregodts P, D’Haese J. A simplified T2-T3 thoracoscopic sympathicolysis technique for the treatment of essential hyperhidrosis: short-term results in 100 patients. J Laparoendoscopic Surg 1996; 6: 151-159

[27] Baumgartner F], Reyes M, Sarkisyan GG et al. Thoracoscopic sympathicotomy for disabling palmar hyperhidrosis: a prospective randomized comparison between two levels. Ann Thorac Surg 2011; 92: 2015-2019

[28] Won HJ, Choi HS, Park KH. Anatomic variations of the intrathoracic nerves and the neural connections of the second and third thoracic sympathetic ganglia to the brachial plexus. Clin Anat 2020 [published online ahead of print]

[29] Chung IH, Oh CS, Koh KS et al. Anatomic variations of the T2 nerve root (including the nerve of Kuntz) and their implications for sympathectomy. J Thorac Cardiovasc Surg 2002; 123: 498-501

[30] Kuntz A. Distribution of the sympathetic rami to the brachial plexus: its relation to sympathectomy affecting the upper extremity. Arch Surg 1927; 15: 871-877

[31] Ramsaroop L, Partab P, Singh B et al. Thoracic origin of a sympathetic supply to the upper limb: the 'nerve of Kuntz' revisited. J Anat 2001; 199: 675-682

[32] Andresen JR, Scheer F, Schlöricke E et al. CT-guided thoracic sympathicolysis versus video-assisted thoracoscopic sympathectomy in the therapeutic concept of severe primary palmar hyperhidrosis. Innov Surg Sci 2020; 5: 254

[33] Vanderhelst E, De Keukeleire T, Verbanck S et al. Quality of life and patient satisfaction after video-assisted thoracic sympathicolysis for essential hyperhidrosis: a follow-up of 138 patients. J Laparoendosc Adv Surg Tech A 2011; 21: 905-909 